\title{
PENGARUH CORPORATE GOVERNANCE DAN KARAKTERISTIK PERUSAHAAN TERHADAP NILAI PERUSAHAAN
}

\author{
FELICIA \\ ARWINA KARMUDIANDRI \\ Trisakti School of Management, Jl. Kyai Tapa No. 20, Jakarta 11440, Indonesia \\ arwina@stietrisakti.ac.id
}

\begin{abstract}
The aim of this research is to acquire managerial ownership, institutional ownership, audit committee, board of commissioner, independent commissioner, firm size, profitability, and financial leverage in affecting firm value in non-financial companies listed in Indonesia Stock Exchange. In this study, the researcher used 94 listed non-financial companies in Indonesia Stock Exchange since 2015 until 2017 that have been selected by purposive sampling method. Multiple linear regressions method is used to analysis data. The result of this research indicates that independent commissioner, profitability, and financial leverage have affect to firm value. While managerial ownership, institutional ownership, audit committee, board of commissioner, and firm size did not significantly impact on firm value.
\end{abstract}

Keywords: Firm value, independent commissioner, profitability, financial leverage

Abstrak: Tujuan penelitian adalah untuk memperoleh kepemilikan manajerial, kepemilikan institusional, komite audit, dewan komisaris, komisaris independen, ukuran perusahaan, profitabilitas, dan leverage keuangan dalam mempengaruhi nilai perusahaan pada perusahaan non-keuangan yang terdaftar di Bursa Efek Indonesia. Dalam penelitian ini, peneliti menggunakan 94 perusahaan non-keuangan yang terdaftar di Bursa Efek Indonesia sejak 2015 hingga 2017 yang telah dipilih dengan metode purposive sampling. Metode regresi linier berganda digunakan untuk menganalisis data. Hasil penelitian ini menunjukkan bahwa komisaris independen, profitabilitas, dan leverage keuangan berpengaruh terhadap nilai perusahaan. Sedangkan kepemilikan manajerial, kepemilikan institusional, komite audit, dewan komisaris, dan ukuran perusahaan tidak berpengaruh signifikan terhadap nilai perusahaan.

Kata kunci: Nilai peusahaan, komisaris independen, profitabilitas, leverage keuangan

\section{PENDAHULUAN}

Perusahaan dalam mendirikan usahanya dituntut untuk memiliki tujuan serta kinerja yang lebih baik agar mampu bersaing dengan para kompetitornya. Dimana, tujuan perusahaan adalah untuk meningkatkan kemakmuran pemegang saham dengan cara meningkatkan nilai perusahaan yang mencerminkan kinerja dari suatu perusahaan.
Jika kinerja perusahaan baik maka return yang diperoleh akan tinggi dan dapat berdampak pada tingkat kemakmuran investor (Meythi 2013, 200). Salah satu indikator yang dapat digunakan untuk mengukur nilai perusahaan adalah harga saham. Harga saham yang mengalami peningkatan akan mendorong nilai perusahaan semakin meningkat, dimana hal ini 
menunjukkan prospek perusahaan di masa depan. Harga saham mencerminkan nilai suatu perusahaan, dimana hal tersebut memengaruhi keputusan investasi dari para investor.

Bentuk kegiatan yang dapat dilakukan untuk meningkatkan nilai perusahaan adalah melalui kegiatan publik. Publik merupakan kegiatan penawaran umum yang dilakukan oleh perusahaan kepada masyarakat, dimana perusahaan-perusahaan tersebut sudah terdaftar dalam Bursa Efek Indonesia (BEI), maka setiap saat publik dapat memperoleh data mengenai pergerakan nilai perusahaan. Peningkatan nilai perusahaan juga dapat tercapai apabila ada kerja sama antara manajemen perusahaan dengan pihak lain yang meliputi shareholder maupun stakeholder dalam membuat keputusan-keputusan keuangan dengan tujuan memaksimumkan modal kerja yang dimiliki (Sukirni 2012, 2). Apabila terdapat keselarasan kepentingan antara kedua belah pihak, maka tidak akan ada permasalahan yang muncul dalam perusahaan. Namun, dalam kondisi yang sebenarnya penyatuan kepentingan antara kedua belah pihak tersebut sering menemui masalah (Borolla 2011, 11).

Perbedaan kepentingan antara manajer perusahaan dengan pemegang saham ini akan menimbulkan konflik yang biasa disebut dengan agency conflict. Agency conflict dapat mengakibatkan kecenderungan manajemen untuk melaporkan laba secara oportunis demi memaksimumkan kepentingan pribadinya (Rupilu 2011, 102). Corporate governance merupakan salah satu cara yang dapat digunakan dalam mengatasi agency conflict sekaligus dapat berdampak dalam meningkatkan nilai perusahaan. Tujuan utama dalam corporate governance adalah untuk menciptakan sistem kontrol dan keseimbangan, dimana hal ini bertujuan untuk mencegah penyalahgunaan sumber daya perusahaan serta mendorong pertumbuhan perusahaan.

Penelitian ini merupakan pengembangan dari penelitian sebelumnya yang dilakukan oleh Debby et al. (2014). Penelitian sebelumnya menggunakan variabel corporate governance yang terdiri dari kepemilikan manajerial, komisaris independen, dan komite audit serta variabel karakteristik perusahaan yang terdiri dari ukuran perusahaan dan profitabilitas. Perbedaan penelitian sekarang dengan penelitian sebelumnya adalah dengan menambahkan variabel independen lainnya guna menentukan faktor-faktor yang memengaruhi nilai perusahaan. Variabel independen lainnya yang digunakan dalam penelitian ini adalah financial leverage (Farooq dan Masood 2016), ukuran dewan komisaris dan kepemilikan institusional (Mukhtaruddin et al. 2014). Periode dan sampel penelitian yang digunakan juga berbeda, dimana pada penelitian ini diambil tiga tahun penelitian yaitu tahun 2015-2017 pada perusahaan non keuangan, sedangkan pada penelitian sebelumnya hanya dua tahun penelitian yaitu tahun 2008-2010 pada perusahaan perbankan.

\section{Agency Theory}

Menurut Jensen dan Meckling $(1976,5)$, teori keagenan (agency theory) menjelaskan bahwa hubungan agensi muncul ketika adanya suatu kontrak dimana satu orang atau lebih (principal) mempekerjakan orang lain (agent) untuk memberikan suatu jasa dan kemudian mendelegasikan wewenang pengambilan keputusan kepada agent tersebut. Bila tujuan dari kedua belah pihak sejalan maka diyakini agent akan menjalankan perusahaan sesuai dengan kepentingan principal.

Namun, pada kenyataannya penyatuan kepentingan antara principal dengan agent sering menimbulkan masalah, dimana masalah yang terjadi antara keduabelah pihak disebut dengan agency problem (Borolla 2011, 11). Masalah ini muncul ketika agent cenderung mengejar kepentingan pribadi dengan melakukan tindakan yang merugikan principal. Tindakan menyimpang yang dilakukan agent ini yang nantinya akan memunculkan biaya 
keagenan (agency cost). Agency Cost dapat diminimalisir dengan penerapan corporate governance yang baik (Rupilu 2011, 103). Adanya penerapan corporate governance, pengawasan terhadap manajemen perusahaan dapat lebih efektif sehingga dapat meningkatkan kinerja dan nilai perusahaan (Wardoyo dan Veronica 2013, 133).

\section{Signaling Theory}

Signaling Theory mengemukakan bagaimana seharusnya perusahaan dapat memberikan sinyal kepada pengguna laporan keuangan, dimana sinyal tersebut berupa informasi mengenai tindakan yang sudah dilakukan oleh manajemen perusahaan untuk merealisasikan keinginan pemilik (Kurniasari dan Warastuti 2015, 33). Para pemakai laporan keuangan akan menggunakan sinyal tersebut untuk meramalkan, membandingkan dan menilai dampak keuangan yang timbul dari keputusan ekonomis yang diambilnya.

Menurut Brigham et al. (2014, 528), sinyal adalah suatu tindakan yang diambil manajemen untuk memberi petunjuk bagi investor tentang bagaimana manajemen memandang prospek perusahaan. Dorongan dalam memberikan sinyal timbul karena adanya asymmetric information antara manajemen (agent) dengan pemilik (principal), dimana principal mengetahui informasi internal perusahaan yang relatif lebih sedikit dan lebih lambat dibandingkan pihak agent. Menurut Nuswandari $(2009,55)$, perusahaan dapat meningkatkan nilai perusahaan dengan cara mengurangi asymmetric information. Perusahaan dapat memberikan sinyal kepada pihak luar berupa informasi keuangan yang dapat dipercaya dan dapat mengurangi ketidakpastian mengenai prospek perusahaan pada masa yang akan datang.

\section{Nilai Perusahaan}

Memaksimalkan nilai perusahaan merupakan suatu arti yang penting bagi perusahaan, karena dengan memaksimalkan nilai perusahaan berarti juga memaksimalkan tujuan utama perusahaan yakni meningkatkan kemakmuran pemegang saham. Nilai perusahaan dianggap suatu konsep yang penting bagi pemegang saham karena nilai perusahaan merupakan indikator bagaimana pasar menilai perusahaan secara keseluruhan. Oleh karena itu bagi perusahaan yang sudah $\mathrm{Go}$ Public, harga saham yang diperjual-belikan di bursa merupakan indikator dalam mengukur nilai perusahaan.

\section{Kepemilikan Manajerial dan Nilai Perusahaan} Kepemilikan manajerial merupakan besaran proporsi saham biasa yang dimiliki oleh manajemen (direksi dan komisaris). Menurut Mukhtaruddin et al. $(2014,4)$, dengan adanya kepemilikan manajerial kepentingan manajemen dan pemegang saham akan bersatu dan akan memberikan dampak positif untuk meningkatkan nilai perusahaan. Penelitian yang dilakukan oleh Lusiana dan Agustina (2017), Muryati dan Suardikha (2014, 422), Mukhtaruddin et al. $(2014,7)$ serta Rizqia et al. $(2013,125)$ menyatakan adanya pengaruh positif kepemilikan manajerial terhadap nilai perusahaan. Sedangkan pada penelitian dari Debby et al. (2014, 85), Hariyanto dan Lestari (2015, 1618), Wida dan Suartana $(2014,587)$ dinyatakan bahwa kepemilikan manajerial tidak berpengaruh terhadap nilai perusahaan.

$\mathrm{H}_{1}$ Terdapat pengaruh kepemilikan manajerial terhadap nilai perusahaan.

\section{Kepemilikan Institusional dan Nilai Perusahaan}

Kepemilikan institusional merupakan persentase saham perusahaan yang dimiliki oleh perusahaan lain dan pemerintah baik yang berada di dalam maupun luar negeri (Susiana dan Herawati 2007, 8). Hal ini dapat memengaruhi struktur kepemilikan perusahaan yang dapat berdampak terhadap nilai perusahaan. Penelitian yang dilakukan oleh 
Mukhtaruddin et al. (2014, 7), menyatakan bahwa kepemilikan institusional tidak berpengaruh terhadap nilai perusahaan. Hasil ini berlawanan dengan penelitian dari Rupilu (2011, 119), Borolla (2011, 22), Muryati dan Suardhika $(2014,423)$ yang menyatakan bahwa kepemilikan institusional memiliki pengaruh positif terhadap nilai perusahaan.

$\mathrm{H}_{2}$ Terdapat pengaruh kepemilikan institusional terhadap nilai perusahaan.

\section{Komite Audit dan Nilai Perusahaan}

Komite audit adalah suatu komite yang dibentuk serta bertanggung jawab kepada dewan komisaris dimana anggotanya diangkat dan diberhentikan oleh dewan komisaris (Widjaja dan Maghviroh 2011, 120). Hasil penelitian dari Debby et al. $(2014,85)$, Mukhtaruddin et al. $(2014,8)$, Siahaan (2013, 141), menyatakan bahwa komite audit tidak berpengaruh terhadap nilai perusahaan. Penelitian yang dilakukan oleh Muryati dan Suardikha (2014, 424), Prastuti dan Budiasih $(2015,125)$ memperoleh hasil bahwa komite audit berpengaruh negatif terhadap nilai perusahaan.

$\mathrm{H}_{3}$ Terdapat pengaruh komite audit terhadap nilai perusahaan.

\section{Ukuran Dewan Komisaris dan Nilai Perusahaan}

Dewan komisaris bertugas untuk mengawasi dan memberikan nasihat kepada direksi (Zarkasyi 2008, 96). Dewan komisaris sebagai organ perusahaan bertugas untuk memastikan bahwa perusahaan melaksanakan corporate governance. Hasil dari penelitian Siahaan $(2013,141)$ menunjukkan bahwa ukuran dewan komisaris berpengaruh positif terhadap nilai perusahaan. Hasil penelitian Wardoyo dan Veronica $(2013,145)$ dan Mukhtaruddin et al. $(2014,6)$ menyatakan ukuran dewan komisaris tidak berpengaruh terhadap nilai perusahaan.
$\mathrm{H}_{4}$ Terdapat pengaruh ukuran dewan komisaris terhadap nilai perusahaan.

\section{Dewan Komisaris Independen dan Nilai Perusahaan}

Dewan komisaris independen adalah anggota dewan komisaris yang tidak terafiliasi dengan direksi. Sebuah perseroan diwajibkan untuk memiliki komisaris independen, yaitu anggota dewan komisaris yang tidak memiliki hubungan dengan anggota dewan komisaris dan direksi, pemegang saham pengendali, serta tidak memiliki hubungan dengan perseroan, yang dapat memengaruhi kemampuannya untuk bertindak independen. Penelitian Sari dan Sanjaya (2018), Sukmadijaya dan Cahyadi (2017), Muryati dan Suardikha $(2014,423)$, Putra (2016, 12), menyatakan bahwa terdapat pengaruh positif antara dewan komisaris independen dan nilai perusahaan. Hasil penelitian dari Wardoyo dan Veronica $(2013,145)$, Siahaan $(2013,141)$, dan Rupilu $(2011,118)$ yang menyatakan bahwa dewan komisaris independen tidak berpengaruh terhadap nilai perusahaan.

$\mathrm{H}_{5}$ Terdapat pengaruh dewan komisaris independen terhadap nilai perusahaan.

\section{Ukuran Perusahaan dan Nilai Perusahaan}

Ukuran perusahaan digambarkan melalui melalui besar kecilnya perusahaan yang ditunjukkan melalui besarnya aset yang dimiliki oleh perusahaan. (Nuraina 2012, 54). Oleh karena itu, ukuran perusahaan dianggap dapat memengaruhi nilai perusahaan karena semakin besar ukuran perusahaan maka akan semakin mudah bagi perusahaan untuk memperoleh sumber pendanaan baik yang bersifat internal maupun eksternal (Prasetyorini 2013, 183). Hasil penelitian yang ditunjukkan oleh Manoppo dan Arie (2016) dan Rupilu (2011, 118), bahwa ukuran perusahaan tidak berpengaruh terhadap nilai perusahaan. Penelitian Lusiana dan Agustina (2017), Sukmadijaya dan Cahyadi (2017), Bernandhi dan Muid (2014, 11), Debby et al. (2014, 85), serta Prasetyorini $(2013,190)$ 
menyatakan bahwa ukuran perusahaan berpengaruh positif terhadap nilai perusahaan.

$\mathrm{H}_{6}$ Terdapat pengaruh ukuran perusahaan penjualan terhadap nilai perusahaan.

\section{Profitabilitas dan Nilai Perusahaan}

Menurut Mardiyati et al. $(2012,6)$, profitabilitas mengukur kemampuan suatu perusahaan dalam menghasilkan keuntungan dari kegiatan bisnis yang dilakukan. Penelitian Sari dan Sanjaya (2018), Lusiana dan Agustina (2017), Sukmadijaya dan Cahyadi (2017), Noviana dan Nelliyana (2017), Debby et al. $(2014,85)$, Saraswathi et al. (2016, 1751), Rizqia et al $(2013,126)$, menunjukkan bahwa profitabilitas berpengaruh positif terhadap nilai perusahaan. Pendapat yang berbeda diutarakan dalam penelitian yang dilakukan oleh Manoppo dan Arie $(2016,494)$, Hariyanto dan Lestari $(2015$, 1621), dimana profitabilitas tidak berpengaruh terhadap nilai perusahaan.

$\mathrm{H}_{7}$ Terdapat pengaruh profitabilitas terhadap nilai perusahaan.

\section{Financial Leverage dan Nilai Perusahaan}

Rasio financial Leverage merupakan rasio yang digunakan untuk mengukur kemampuan perusahaan dalam memenuhi kewajibannya, baik jangka pendek maupun jangka panjang (Stiyarini dan Santoso 2016, 4). Penelitian yang dilakukan oleh Sari dan Sanjaya (2018), Sujoko dan Soebiantoro (2007, 46), Sukmadijaya dan Cahyadi (2017), dan Sianturi $(2015,292)$ menunjukkan bahwa financial leverage berpengaruh negatif terhadap nilai perusahaan. Hasil penelitian Isnaini $(2017,647)$, Prasetyorini (2013, 190-191), Rompas (2013, 261), dan Ogolmagai (2013, 87-88) menunjukkan bahwa financial leverage tidak berpengaruh terhadap nilai perusahaan.

$\mathrm{H}_{8}$ Terdapat pengaruh financial leverage terhadap nilai perusahaan.

\section{METODA}

Obyek penelitian yang digunakan sebagai populasi adalah perusahaanperusahaan yang terdaftar di Bursa Efek Indonesia (BEI) periode 2015 sampai dengan 2017. Pemilihan sampel dalam penelitian menggunakan pendekatan non probability random sampling dengan metode purposive sampling. Purposive sampling adalah sebuah teknik yang digunakan dalam pengambilan sampel dengan menetapkan persyaratan tertentu yang harus dipenuhi oleh anggota populasi untuk dapat dipilih sebagai sampel penelitian (Erawati 2015, 76).

Tabel 1 Prosedur Pemilihan Sampel

\begin{tabular}{|c|c|c|c|}
\hline No. & Keterangan & Jumlah & Data \\
\hline 1 & $\begin{array}{l}\text { Perusahaan non keuangan yang terdaftar di Bursa Efek Indonesia secara } \\
\text { konsisten selama tahun } 2015 \text { sampai dengan tahun } 2017 \text {. }\end{array}$ & 429 & 1287 \\
\hline 2 & $\begin{array}{l}\text { Perusahaan non keuangan yang tidak menerbitkan laporan keuangan tahunan } \\
\text { yang berakhir pada tanggal } 31 \text { Desember. }\end{array}$ & (12) & (36) \\
\hline 3 & $\begin{array}{l}\text { Perusahaan non keuangan yang tidak menyajikan laporan keuangan dengan } \\
\text { menggunakan mata uang rupiah (Rp). }\end{array}$ & (79) & $(237)$ \\
\hline 4 & $\begin{array}{l}\text { Perusahaan non keuangan yang tidak melaporkan laba bersih secara berturut- } \\
\text { turut selama periode penelitian. }\end{array}$ & (134) & $(402)$ \\
\hline 5 & Perusahaan non keuangan yang tidak memiliki kepemilikan manajerial & (107) & (321) \\
\hline \multirow[t]{2}{*}{6} & Perusahaan non keuangan yang tidak memiliki kepemilikan institusional. & (3) & (9) \\
\hline & Total perusahaan non keuangan yang digunakan sebagai sampel penelitian & 94 & 282 \\
\hline
\end{tabular}


Nilai perusahaan merupakan konsep penting bagi investor karena nilai perusahaan merupakan indikator bagaimana pasar menilai perusahaan secara keseluruhan. Dalam penelitian ini, nilai perusahaan diukur dengan skala rasio yaitu menggunakan Tobin's $Q$ yang mengacu pada penelitian yang dilakukan oleh Debby et al. (2014) dengan rumus sebagai berikut:

$$
F V=\frac{(M V E+D)}{(B V E+D)}
$$

Kepemilikan manajerial merupakan saham perusahaan yang dimiliki oleh manajemen di dalam perusahaan (Jensen dan Meckling 1976, Debby et al. 2014). Kepemilikan institusional merupakan persentase saham perusahaan yang dimiliki oleh perusahaan lain dan pemerintah baik yang berada di dalam maupun luar negeri (Susiana dan Herawati 2007, Mukhtaruddin et al. 2014).

Komite audit adalah suatu komite yang dibentuk serta bertanggung jawab kepada dewan komisaris dimana anggotanya diangkat dan diberhentikan oleh dewan komisaris (Widjaja dan Maghviroh 2011, Debby et al. 2014). Ukuran Dewan Komisaris adalah dewan yang bertugas untuk mengawasi dan memberikan nasihat kepada direksi (Zarkasyi 2008, Mukhtaruddin et al. 2014). Dewan komisaris independen adalah anggota dewan komisaris yang tidak terafiliasi dengan direksi (Debby et al. 2014).

Ukuran perusahaan digambarkan melalui besar kecilnya perusahaan yang ditunjukkan melalui besarnya aset yang dimiliki oleh perusahaan (Nuraina 2012, Debby et al. 2014). Profitabilitas mengukur kemampuan suatu perusahaan dalam menghasilkan keuntungan dari kegiatan bisnis yang dilakukan (Mardiyati et al. 2012). Profitabilitas diukur menggunakan skala rasio dengan melakukan perbandingan antara laba bersih setelah pajak terhadap total ekuitas (Debby et al. 2014).

Financial leverage diukur dengan menggunakan proksi Debt to Equity Ratio (DER) yang merujuk pada Farooq dan Masood (2016). Dalam penelitian ini model regresi berganda yang digunakan untuk menguji pengaruh kepemilikan manajerial, kepemilikan institusional, komite audit, ukuran dewan komisaris, dewan komisaris independen, ukuran perusahaan, profitabilitas, dan financial leverage terhadap nilai perusahaan. Pengujian ini memiliki tingkat kesalahan yang dapat ditolerir (a) sebesar $5 \%$. Persamaan regresi berganda dalam penelitian ini adalah sebagai berikut:

$F V=\beta_{0}+\beta 1 M N J R L+\beta 2 I N S T+\beta 3 K A+$ $\beta 4 \mathrm{UDK}+\beta 5 \mathrm{DKI}+\beta 6 \mathrm{SIZE}+\beta 7 \mathrm{ROE}+\beta 8 \mathrm{DER}$

$+\varepsilon$

Keterangan:

$\beta_{0}=$ Konstanta;

$\beta 1-\beta 8=$ Koefisien Regresi dari masing-masing variabel bebas;

FV= Nilai Perusahaan (Tobin's Q);

MNJRL= Kepemilikan Manajerial;

INST= Kepemilikan Institusional;

$\mathrm{KA}=$ Komite Audit;

UDK= Ukuran Dewan Komisaris;

DKI= Dewan Komisaris Independen;

SIZE= Ukuran Perusahaan;

$\mathrm{ROE}=$ Return on Equity;

$\mathrm{DER}=$ Debt to Equity Ratio;

$\varepsilon=$ error term atau kesalahan pengganggu

\section{HASIL DAN PEMBAHASAN}

Statistik deskriptif penelitian sebagai mana terlihat pada tabel berikut. 
Tabel 2 Statistik Dekriptif

\begin{tabular}{lrrrr}
\hline \multicolumn{1}{c}{ Variabel } & \multicolumn{1}{c}{ Minimum } & Maksimum & \multicolumn{1}{c}{ Rerata } & Deviasi Standar \\
\hline FV & 0,2132 & 23,2858 & 1,829071 & 2,4247330 \\
MNJRL & 0,0000 & 0,4181 & 0,050989 & 0,0901744 \\
INST & 0,0514 & 0,9996 & 0,723534 & 0,1985505 \\
KA & 2,0000 & 6,0000 & 3,088652 & 0,4415425 \\
UDK & 1,0000 & 22,0000 & 4,496454 & 2,3731119 \\
DKI & 0,2000 & 1,0000 & 0,404688 & 0,1066506 \\
SIZE & 10,8136 & 14,4708 & 12,591810 & 0,7092516 \\
ROE & 0,0004 & 1,6099 & 0,142724 & 0,1990203 \\
DER & 0,0738 & 13,5432 & 1,130287 & 1,3461445 \\
\hline
\end{tabular}

Tabel 3 Hasil Uji t

\begin{tabular}{lcc}
\hline Variabel & B & Sig. \\
\hline Konstanta & $-1,057$ & 0,478 \\
MNJRL & 0,096 & 0,921 \\
INST & 0,710 & 0,108 \\
KA & $-0,237$ & 0,194 \\
UDK & 0,045 & 0,232 \\
DKI & 2,783 & 0,000 \\
SIZE & 0,065 & 0,595 \\
ROE & 10,749 & 0,000 \\
DER & $-0,519$ & 0,000 \\
\hline
\end{tabular}

Hasil dari pengujian yang dilakukan menunjukkan bahwa kepemilikan manajerial tidak berpengaruh terhadap nilai perusahaan. Kepemilikan manajerial yang besar tidak menentukan bahwa manajemen mampu menyejajarkan kepentingan manajemen dengan pemegang saham, sehingga tujuan dalam mencapai nilai perusahaan tidak dapat terealisasi (Wida dan Suartana 2014, 586). Hasil ini didukung oleh penelitian dari Debby et al. (2014, 85), Hariyanto dan Lestari $(2015,1618)$, Wida dan Suartana $(2014,587)$.

Hasil dari pengujian yang dilakukan menunjukkan bahwa kepemilikan institusional tidak berpengaruh terhadap nilai perusahaan. Kepemilikan institusi dianggap kurang efektif dalam mengontrol dan mengawasi kinerja perusahaan. Hasil penelitian ini konsisten dengan penelitian dari Mukhtaruddin et al. $(2014,7)$.

Hasil dari pengujian yang dilakukan menunjukkan bahwa komite audit tidak berpengaruh terhadap nilai perusahaan Hasil ini bisa disebabkan komite audit tidak memiliki latar belakang pada bidang akuntansi ataupun keuangan sehingga peran komite audit dianggap kurang efektif (Mukhtaruddin et al. 2014, 9). Hasil penelitian yang dilakukan oleh Debby et al. (2014, 85), Mukhtaruddin et al. $(2014,8)$, dan Siahaan $(2013,141)$ mendukung hasil dari pengujian yang dilakukan.

Hasil dari pengujian yang dilakukan menunjukkan bahwa ukuran dewan komisaris tidak berpengaruh terhadap nilai perusahaan. Dewan komisaris dianggap tidak berpengaruh dalam meningkatkan nilai perusahaan yang 
dimungkinkan karena fungsi dewan komisaris dalam suatu perusahaan hanya sebagai controller dan tidak terlibat langsung dalam kegiatan operasi perusahaan sehingga dianggap tidak terlalu berpengaruh terhadap nilai perusahaan (Wardoyo dan Veronica 2013, 145). Hasil ini konsisten dengan penelitian dari Wardoyo dan Veronica $(2013,145)$ dan Mukhtaruddin et al. $(2014,6)$.

Hasil dari pengujian yang dilakukan menunjukkan bahwa dewan komisaris independen berpengaruh terhadap nilai perusahaan. Semakin tinggi proporsi dewan komisaris independen dalam perusahaan, diharapkan dapat melakukan tugas pengawasan dan pemberian nasihat kepada direksi secara efektif. Keberadaan dewan komisaris independen dapat menyebabkan manajemen untuk bekerja lebih baik sehingga dapat memberikan nilai tambah kepada perusahaan (Debby et al. 2014, 83). Penelitian ini konsisten dengan penelitian dari Muryati dan Suardikha $(2014,423)$, Putra $(2016,12)$.

Hasil dari pengujian yang dilakukan menunjukkan bahwa ukuran perusahaan tidak berpengaruh terhadap nilai perusahaan. Investor yang membeli saham sebuah perusahaan tidak hanya ditinjau dari seberapa besar aset perusahaan, tetapi juga dari sisi lain seperti: laporan keuangan, nama baik, dan juga kebijakan dividen sehingga ukuran perusahaan belum mampu menjadi faktor utama yang dapat memengaruhi nilai perusahaan (Manoppo dan Arie 2016, 494). Hasil penelitian ini didukung dengan penelitian dari Manoppo dan Arie (2016) dan Rupilu $(2011,118)$.

Hasil dari pengujian yang dilakukan menunjukkan bahwa profitabilitas berpengaruh terhadap nilai perusahaan. Semakin tinggi nilai profit yang dihasilkan oleh perusahaan menandakan semakin tinggi nilai perusahaan, karena profit yang tinggi akan memberikan indikasi prospek perusahaan yang baik sehingga dapat menarik perhatian investor untuk ikut meningkatkan permintaan saham. Permintaan saham yang meningkat akan meningkatkan nilai perusahaan (Mardiyati 2012, 16). Penelitian ini konsisten dengan penelitian dari Debby et al. $(2014,85)$, Saraswathi et al. (2016, 1751), Rizqia et al $(2013,126)$

Hasil dari pengujian yang dilakukan menunjukkan bahwa financial leverage berpengaruh terhadap nilai perusahaan. Hal ini dikarenakan jika perusahaan memiliki tingkat hutang yang tinggi akan menyebabkan beban bunga yang harus dibayarkan oleh perusahaan juga tinggi, dimana akan berdampak pada kemampuan perusahaan dalam menghasilkan laba dan akan memengaruhi investor dalam menginvestasikan dananya atau membeli saham suatu perusahaan (Sianturi 2015, 294). Hal tersebut akan berdampak pada menurunnya kepercayaan investor dan akan berakibat pada menurunnya nilai perusahaan. Penelitian ini didukung oleh penelitian dari Sujoko dan Soebiantoro $(2007,46)$ dan Sianturi $(2015,292)$.

\section{PENUTUP}

Penelitian yang dilakukan menunjukkan
bahwa dewan komisaris independen,
profitabilitas, dan financial leverage memiliki
pengaruh terhadap nilai perusahaan.
Sementara kepemilikan manajerial, kepemilikan
institusional, komite audit, ukuran dewan
komisaris, ukuran perusahaan tidak memiliki
pengaruh terhadap nilai perusahaan.
Keterbatasan dalam penelitian yang dilakukan
adalah hanya menggunakan 8 variabel
independen dan periode penelitian hanya 3
tahun, yakni tahun 2015-2017. Untuk penelitian
selanjutnya dapat menambahkan variabel lain
dalam penelitian, seperti Corporate Social
Responsibility (CSR) dan kebijakan dividen.




\section{REFERENSI:}

Bernandhi, Riza dan Abdul Muid. 2014. Pengaruh Kepemilikan Manajerial, Kepemilikan Institusional, Kebijakan Dividen, Leverage, dan Ukuran Perusahaan terhadap Nilai Perusahaan. Diponegoro Journal of Accounting, 3(1), 1-14.

Borolla, Johanis Darwin. 2011. Analisis Pengaruh Struktur Kepemilikan terhadap Nilai Perusahaan). P3M STIE Bank BPD Jateng, 7(1), 11-24.

Brigham, Eugene F., Joel F. Houston, Hsu Jun Ming, Kong Yoon Kee, dan A.N. Bany Ariffin. 2014. Essential of Financial Management $3^{\text {rd }}$ Edition. Singapura: Cengange Learning.

Debby, Julia Farah, Mukhtaruddin, Emylia Yuniarti, Dewa Saputra, dan Abukosim. 2014. Good Corporate Governance, Company's Characteristics and Firm's Value: Empirical Study of Listed Banking on Indonesian Stock Exchange. GSTF Journal on Business Review (GBR), 3(4), 81-88.

Dewi Lusiana dan Dewi Agustina. 2017. Faktor-faktor yang mempengaruhi nilai perusahaan pada perusahaan non keuangan. Jurnal Bisnis dan Akuntansi, 19(1), 81-91.

Erawati, Diana. 2015. Pengaruh Likuiditas, Manajemen Aset, Manajemen Liabilitas, dan Profitabilitas terhadap Harga Saham Pasar/Buku Pada Perusahaan Makanan dan Minuman yang Terdaftar di BEI Periode Tahun 2008-2012. E-Jurnal IImu Manajemen MAGISTRA, 1(1), 71-87.

Farooq, Muhammad Azhar dan Ahsan Masood. 2016. Impact of Financial Leverage on Value of Firms: Evidence from Cement Sector of Pakistan. Research Journal of Finance and Accounting, 7(9), 73-77.

Hariyanto, Marina Suzuki dan Putu Vivi Lestari. 2015. Pengaruh Struktur Kepemilikan, IOS, dan ROE terhadap Nilai Perusahaan pada Perusahaan Food and Beverage. E-Jurnal Manajemen Ubud, 4(4), 1599-1626.

Isnaini, Nurizza Arsyi. 2017. Pengaruh Karakteristik Perusahaan terhadap Nilai Perusahaan: Corporate Social Responsibility sebagai Variabel Intervening. Jurnal IImu dan Riset Akuntansi, 6(2), 631-651.

Jensen, Michael C., William H. Meckling. 1976. Theory of the Firm: Managerial Behaviour, Agency Costs and Ownership Structure. Journal of Financial Economics, 3(4), 305-360.

Kurniasari, Widuri dan Yusni Warastuti. 2015. The Relationship between CSR and Profitability to Firm Value In SriKehati Index. Jurnal Economic Behaviour, 5(1), 31-41.

Manoppo, Heven dan Fitty Valdi Arie. 2016. Pengaruh Struktur Modal, Ukuran Perusahaan dan Profitabilitas terhadap Nilai Perusahaan Otomotif yang Terdaftar di Bursa Efek Indonesia Periode 2011-2014. Jurnal EMBA, 4(2), 485-497.

Mardiyati, Umi, Gatot Nazir Ahmad, dan Ria Putri. 2012. Pengaruh Kebijakan Dividen, Kebijakan Hutang dan Profitabilitas terhadap Nilai Perusahaan Manufaktur yang Terdaftar di Bursa Efek Indonesia (BEI) Periode 2005-2010. Jurnal Riset Manajemen Sains Indonesia, 3(1), 1-17.

Meythi. 2013. Rasio Keuangan Terbaik untuk Memprediksi Nilai Perusahaan. Jurnal Keuangan dan Perbankan, 17(2), 200-210.

Mukhtaruddin, Relasari, dan Messa Felmania. 2014. Good Corporate Governance Mechanism, Corporate Social Responsibility Disclosure on Firm Value: Empirical Study on Listed Company in Indonesia Stock Exchange. International Journal of Finance and Accounting Studies, 2(1), 1-10.

Muryati, Ni Nyoman Tri Sariri dan I Made Sadha Suardikha. 2014. Pengaruh Corporate Governance pada Nilai Perusahaan. E-Jurnal Akuntansi Universitas Udayana, 9(2), 411-429.

Noviana, Kezia Crusita dan Nelliyana. 2017. Faktor-Faktor yang mempengaruhi Nilai Perusahaan non keuangan yang terdaftar dl BEI, Jurnal Bisnis dan Akuntansi, 19(1a-3), 168-176.

Nuraina, Elva. 2012. Pengaruh Kepemilikan Institusional dan Ukuran Perusahaan terhadap Kebijakan Hutang dan Nilai Perusahaan. Akrual: Jurnal Akuntansi, 4(1), 51-70.

Nuswandari, Cahyani. 2009. Pengaruh Corporate Governance Perception Index terhadap Kinerja Perusahaan pada Perusahaan yang Terdaftar di Bursa Efek Jakarta. Jurnal Bisnis dan Ekonomi, 16(2), 70-84.

Ogolmagai, Natalia. 2013. Leverage Pengaruhnya terhadap Nilai Perusahaan pada Industri Manufaktur yang Go Public di Indonesia. Jurnal Ekonomi, Manajemen, Bisnis, dan Akuntansi, 1(3), 81-89. 
Prasetyorini, Bhekti Fitri. 2013. Pengaruh Ukuran Perusahaan, Leverage, Price Earning Ratio dan Profitabilitas terhadap Nilai Perusahaan. Jurnal IImu Manajemen, 1(1), 182-196.

Prastuti, Ni Ketut Karlina dan I Gusti Ayu Nyoman Budiasih. 2015. Pengaruh Good Corporate Governance pada Nilai Perusahaan dengan Moderasi Corporate Social Responsibility. E-Jurnal Akuntansi Universitas Udayana, 13(1), 114-129.

Putra, Adhitya Agri. 2016. Pengaruh Good Corporate Governance terhadap Nilai Perusahaan. Jurnal Ekonomi KIAT, 27(2), 1-16.

Rizqia, Dwita Ayu, Siti Aisjah, dan Sumiati. 2013. Effect of Managerial Ownership, Financial Leverage, Profitability, Firm Size, and Investment Opportunity on Dividend Policy and Firm Value. Research Journal of Finance and Accounting, 4(11), 120-130.

Rompas, Gisela Prisilia. 2013. Likuiditas, Solvabilitas, dan Rentabilitas terhadap Nilai Perusahaan yang Terdaftar di Bursa Efek Indonesia. Jurnal EMBA, 1(3), 252-262.

Rupilu, Wilsna. 2011. Pengaruh Mekanisme Corporate Governance terhadap Kualitas Laba dan Nilai Perusahaan pada Perusahaan Manufaktur yang Terdaftar di Bursa Efek Indonesia. Jurnal Akuntansi dan Manajemen Bisnis. dan Sektor Publik (JAMBSP), 8(1), 101-127.

Saraswathi, Ida Ayu Anggawulan, I Gst. Bgs. Wiksuana, dan Henny Rahyuda. 2016. Pengaruh Risiko Bisnis, Pertumbuhan Perusahaan dan Struktur Modal terhadap Profitabilitas serta Nilai Perusahaan Manufaktur. E-Jurnal Ekonomi dan Bisnis Universitas Udayana, 5(6), 1729-1756.

Sari, Dwi P.K. dan Riki Sanjaya. 2018. Pengaruh Good Corporate Governance, dan Karakteristik Perusahaan terhadap Nilai Perusahaan. Jurnal Bisnis dan Akuntansi, 20(1), 21-32.

Siahaan, Fadjar O.P., 2013. The Effect of Good Corporate Governance Mechanism, Leverage, and Firm Size on Firm Value. GSTF International Journal on Business Review (GBR), 2(4), 137-142.

Sianturi, M. Wanti Ernita. 2015. Pengaruh Kinerja Keuangan terhadap Nilai Perusahaan Manufaktur Sektor Industri Barang Konsumsi di BEI. E-Journal IImu Administrasi Bisnis. 3(2), 282-296.

Stiyarini dan Bambang Hadi Santoso. 2016. Pengaruh Kinerja Keuangan terhadap Nilai Perusahaan pada Perusahaan Jasa Telekomunikasi. Jurnal IImu dan Riset Manajemen, 5(2), 1-21.

Sujoko dan Ugy Soebiantoro. 2007. Pengaruh Struktur Kepemilikan Saham, Leverage, Faktor Intern dan Faktor Ekstern terhadap Nilai Perusahaan (Studi Empirik pada Perusahaan Manufaktur dan Non Manufaktur di Bursa Efek Jakarta). Jurnal Ekonomi Manajemen, 9(1), 41-48.

Sukirni, Dwi. 2012. Kepemilikan Manajerial, Kepemilikan Institusional, Kebijakan Dividen, dan Kebijakan Hutang Analisis terhadap Nilai Perusahaan. Accounting Analysis Journal, 1(2), 1-12.

Sukmadijaya, Pedro dan Ignes Januar Cahyadi. 2017. Faktor-Faktor yang mempengaruhi Nilai Perusahaan manufaktur. Jurnal Bisnis dan Akuntansi, 19(1a-1), 32-41.

Susiana dan Arleen Herawati. 2007. Analisis Pengaruh Independensi Mekanisme Corporate Governance dan Kualitas Audit terhadap Integritas Laporan Keuangan. Simposium Nasional Akuntansi X 26-28 Juli 2007.

Wardoyo dan Theodora Martina Veronica. 2013. Pengaruh Good Corporate Governance, Corporate Social Responsibility, dan Kinerja Keuangan terhadap Nilai perusahaan. Jurnal Dinamika Manajemen (JDM), 4(2), 132-149.

Wida P. D, Ni Putu dan I Wayan Suartana. 2014. Pengaruh Kepemilikan Manajerial dan Kepemilikan Institusional pada Nilai Perusahaan. E-Jurnal Akuntansi Universitas Udayana, 9(3), 575-590.

Widjaja, Fendi Permana dan Rovila El Maghviroh. 2011. Analisis Perbedaan Kausalitas Laba dan Nilai Perusahaan Sebelum dan Sesudah Adanya Komite pada Bank-Bank Go Public di Indonesia. The Indonesian Accounting Review, 1(2), 117-134.

Zarkasyi, Moh. Wahyudin. 2008. Good Corporate Governance pada Badan Usaha Manufaktur, Perbankan, dan Jasa Keuangan Lainnya. Bandung: Alfabeta. 